Article

\title{
A Regional Perspective on Urbanization and Climate-Related Disasters in the Northern Coastal Region of Central Java, Indonesia
}

\author{
Iwan Rudiarto * (D), Wiwandari Handayani and Jawoto Sih Setyono \\ Department of Urban and Regional Planning, Diponegoro University, Semarang 50275, Indonesia; \\ wiwandari.handayani@pwk.undip.ac.id (W.H.); jawoto.setyono@pwk.undip.ac.id (J.S.S.) \\ * Correspondence: iwan.rudiarto@undip.ac.id; Tel.: +62-24-76486821
}

Received: 4 January 2018; Accepted: 10 March 2018; Published: 12 March 2018

\begin{abstract}
Indonesia, as an archipelagic nation, has about 150 million people $(60 \%)$ living in coastal areas. Such communities are increasingly vulnerable to the effects of change, in the form of sea level rise and stronger, more intense storms. Population growth in coastal areas will also increase the disaster risk mainly because of climate change-related effects such as flooding, droughts, and tidal floods. This study examines the dynamic changes of urban population and urban villages in three decadal periods, from 1990, 2000, to 2010. To highlight different disasters that are increasingly tied to climate change, the analysis was conducted in the northern coastal area of Central Java province using village potential (PODES) data, which are routinely collected by the government. Results show that about $41 \%$ of people in Central Java province live in the northern coastal region and $50 \%$ live in urban areas. The numbers of hazard events within a distance range of $0-40 \mathrm{~km}$ from the shoreline are: flooding (non-tidal) - 335; tidal flooding - 65; and droughts-28. Based on this study, about half of flood disasters (non-tidal) occurred within $10 \mathrm{~km}$ of the shoreline, while tidal flooding accounted for $80 \%$. Most of the climate-related disasters were found in rural areas at low levels of population growth, while in urban areas the disasters were found to be associated in less than $1 \%$ and in more than $3 \%$ of population growth.
\end{abstract}

Keywords: population growth; climate-related disasters; hazard events; northern coast of Central Java

\section{Introduction}

Climate change is a global phenomenon increasingly associated with negative impacts on human activities and society. A growing body of research also shows that climate change constitutes a serious threat to the sustainability of urban development in many countries, especially with a large number of cities located in coastal (low-lying) areas experiencing increasing risk to human development and economic losses [1,2]. Climate change has a significant impact on natural disasters around the world. Natural disasters include biological, meteorological, geophysical, hydrological, and climatological phenomena [3]. Climate-related disasters are mostly related to hydro-meteorological events and include floods, tidal flooding, landslides, windstorms, heatwaves, and fires [4,5]. Floods and droughts are regarded as the most frequent disasters occurring all over the world, especially in Asia. Floods and droughts happen naturally due to the evaporation process, but the risks are compounded by human activities. In terms of climate change, floods take place mainly because of heavy rainfall, and inundations also occur due to tidal flooding from sea-level rise. Changing rainfall pattern happens as a result of changing precipitation associated with climate change. Similarly, drought is defined as a situation of deficiency in water supply, which can also be due to the impact of changing precipitation patterns. In coastal Bangladesh, for instance, high rainfall and rising seas have also caused a severe 
problem for different coastal areas, including impacts such as salinity [6]. There are also similar issues taking place in Rio de Janeiro, Brazil [7], and Vietnam [8].

Most climate-related disasters, such as floods, tidal flooding, and windstorms, affect coastal areas. The coastal area is a dynamic area where there is an interaction between land, water, and the atmosphere, with human activity also playing a part [9]. Due to this dynamic character, coastal areas are also considered preferable to inland areas in terms of settlement. High population density, infrastructure development, and other supporting facilities have made the coastal urban areas the most dynamic areas and a major destination for people to live, and therefore human settlements were concentrated in this area $[10,11]$. Urbanization obviously changes the global environment of many cities across the world and will continue in the future [12,13]. Furthermore, coastal areas are at risk not only because of climate change impacts but also from the combined impacts arising from rapid urbanization. More flood events were found in areas where urbanization had taken place and changed land surface properties [14-16]. We define urbanization as taking place if the share of people who live in an urban area is higher than the rate of urban population growth [17].

The increasing urban population in coastal areas has indeed reshaped coastal geographies and the built environment, and it is often found that urbanization processes are not adaptable to future climate change where potential disruptive effects include the potential for large-scale disasters such as flooding, overproduction, energy inefficiency, and other environmental threats [18]. The Asian Cities Climate Change Resilience Network (ACCCRN) Program highlights the experiences of 10 cities planning for resilience [19]. One of the key findings from the ACCCRN initiatives is that climate change impact is closely related to the urbanization phenomena. Large and growing populations are increasingly experiencing higher levels of vulnerability in coastal areas from the impacts of climate change, such as sea-level rise [20-23]. Migration patterns from rural to urban areas due to disaster risks were found in developing countries that were characterized by low-income urban settlements with about -30 million of the poorest people moving from rural to urban areas per year [24,25]. This phenomenon is also found in most Indonesian cities located in coastal areas, particularly on the island of Java, where about $60 \%$ of Indonesia's total population lives [26]. From a total of 118 districts/cities on Java Island, more than half are located in the northern coastal areas [27]. Different activities in these regions have evolved from basic coastal activities utilizing land and water resources from surrounding areas into more urbanized activities such as industrial and service sectors [10].

The transformation of activities in the northern coastal areas of Java has led to a concentration of development and, consequently, the island become more susceptible to various kinds of natural hazards such as flooding, land subsidence, and coastal inundation [20,28,29]. It is believed that these are due to urbanization pressures and environmental change. Coupled with the existence of climate change, environmental degradation as part of the ill effects of the current trend of urbanization in coastal areas has further deteriorated the environment and created new hazards. Overall, the high concentration of housing and people has indeed resulted in coastal areas becoming more prone to various climate change-related coastal disasters. The increased exposure is evident in various ways, and therefore, climate change impact in coastal areas is of a major concern around the world [30,31].

There are some studies connecting climate change, climate hazards, and urbanization. Most of them focus on phenomena in particular cities. For instance, spatial vulnerability assessments were developed for Haikou, a coastal city in China [32]; flood risk assessments due to climate change were elaborated upon in Addis Ababa City [33]; urbanization and increasing vulnerability were studied in three Sri Lankan cities [34]; the increasing vulnerability of three different cities of coastal Central Java was revealed [20]; a study on future urban flooding explored climate change impacts in Can Tho City, Vietnam [35]; and an examination of climate change phenomena in relation to urbanization was undertaken in the Yangtze River Delta [18]. So far, the attention has been focused on tools to measure the vulnerability of a particular city but not to explicitly connect it with urbanization (i.e., differences in terms of urban and rural status) on a regional level. Therefore, this article is aimed at connecting climate-related disasters and urbanization from a more regional perspective. The scope of this paper 
is how different types of climate-related disasters occur in the northern coastal region of Central Java in terms of population growth rate, density rate, and distance from the coastline. To highlight development status, we also provide context for the urban and rural conditions from different periods to figure out changes in specific regions in the northern coastal areas of Central Java.

\section{Materials and Methods}

\subsection{Study Area}

The northern coastal area of Central Java was selected as the study area. Coastal area boundaries in this research are defined as the district administrative boundaries. All districts located along the northern coastal area of Central Java are regarded as the research area. Administratively, there are 14 cities/regencies in the northern coastal regions, of which four are cities (Tegal, Pekalongan, Semarang, and Kudus) and 10 others are regencies (Brebes, Tegal, Pemalang, Pekalongan, Batang, Kendal, Demak, Jepara, Pati, and Rembang). In total, there are 3151 villages/urban villages within 192 sub-districts. The northern coastal area of Central Java extends from Rembang Regency in the east to Brebes Regency in the west. The total length from east to west is about $427 \mathrm{~km}$, which covers Pemali Comal area (Brebes-Kendal) for about $163 \mathrm{~km}$, Jratun Area (Kendal-Demak) for $77 \mathrm{~km}$, and Seluna Area (Demak-Rembang) for $187 \mathrm{~km}$ [36]. From the shoreline, the study area covers about $30 \mathrm{~km}$, on average, stretching from the north to the south (see Figure 1 for demarcation).

In terms of development, northern coastal areas were considered the most developed region in Central Java. The plains of the northern coast are strategic development locations as they are relatively flat and have adequate infrastructure and access [37]. Development along the northern coast is also due to the historical development policies of the colonial period and extended by Indonesian Government policy to make the northern part of Central Java into a major development corridor, connecting three big cities (Semarang in the middle, Surabaya in the east, and Jakarta in the west). Figure 1 shows the location of the research.

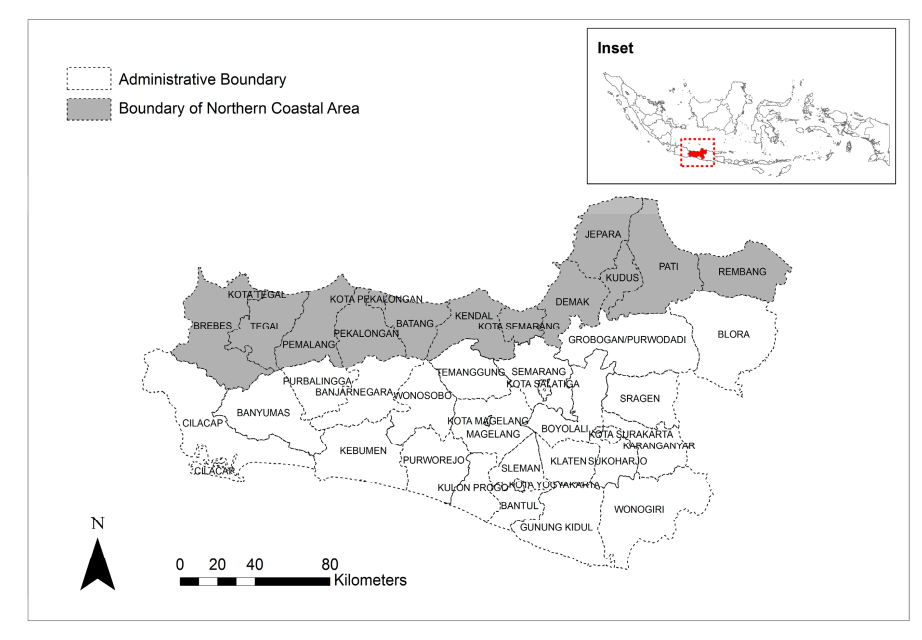

Figure 1. Study area.

\subsection{Data Collection}

Village potential (known as Potensi Desa or PODES) data collected by the Central Bureau of Statistic (BPS) were used. Data were classified into two major areas, i.e., urbanization and climate-related disasters. Data on urbanization are related to population, density, and urban-rural status from 1990, 2000, and 2010, while data on climate-related disasters are represented by the number of floods, tidal floods, and drought events in 2010. Those three kinds of disaster data were identified from 3151 villages/urban villages exposed to disasters in the study area. With the large numbers of villages/urban areas, the climate-related disasters in the study area are expected to have a spatial 
correlation. As this study aims to show the kind of disasters within the northern coastal area, data on floods, tidal floods, and drought events in 2010 were used. Updated data are not available yet. The division of different disasters was intended to show and to compare disasters in different locations. Concerning the context of this research, the data on population and density growth, as well as built-up areas, were used to show the frequency of each kind of disaster in different villages and urban areas distributed in the study area.

\subsection{Methods}

PODES data were transformed into spatially explicit data with Geographical Information System (GIS)-based software to show the data availability in each village/urban village. The spatially explicit data were then classified following the map classification. All spatial explicit data in this study are managed and organized under GIS as it has better database management capability than other information systems. The ability of GIS to manage and analyze data is highly reliable since the data can be spatially arranged into different layers [38]. These different layers of data, representing various spatial data, can further be combined, analyzed, and visualized into the same format and connected through a coordinate system.

\subsubsection{Map Classification}

Map classification was applied for density, urban-rural status, population growth, and distance from coastline. Data from villages/urban villages were identified and classified to identify built-up area, population, and density for the respective year. Population density was classified into five classes and urban-rural status into four classes, identified from the built-up area data in 1990, 2000, and 2010. Population growth was classified into four classes with different percentage classifications. Disaster distribution in the study area was described through a distance classification from the coastline, which was done by a buffering technique in GIS. The intention of distance classification is to show the distribution of climate-related disasters occurring in the study area. Table 1 shows the classifications applied in this study.

Table 1. Data classification.

\begin{tabular}{cc}
\hline Data & Classification \\
\hline Population Density (persons $/ \mathrm{km}^{2}$ ) & $<100,101-400,401-1000,>1000$ \\
Urban-Rural Status (number) & urban in 2010, urban in 2000-2010, urban in 1990-2000-2010, and rural in 2000-2010 \\
Population Growth (\%) & $<1.00 \%, 1.00-1.99 \%, 2.00-3.00 \%,>3.00 \%$ \\
Distance from Coastline $(\mathrm{km})$ & $<5 \mathrm{~km}, 5-10 \mathrm{~km}, 10-20 \mathrm{~km}, 20-40 \mathrm{~km},>40 \mathrm{~km}$ \\
\hline
\end{tabular}

\subsubsection{Population Growth and Density}

As mentioned before, data on population in this study were derived from the PODES data collected and elaborated by BPS. PODES data are census data, surveyed and collected every 10 years by a national program. Population data were compared from different years to see the growth in specific periods. Therefore, population growth is the number that shows the population change within a specific period and is represented as a percentage of the initial population to identify growth rates. This study used a geometric method in calculating the population growth as applied by BPS. Geometric growth refers to a situation where successive changes in a population differ by a constant ratio [39]. The geometric population growth $(r)$ is calculated as follows:

$$
r=\left(P_{t} / P_{0}\right)^{1 / t}-1
$$

where,

$r=$ population growth

$P_{t}=$ Population in year $t$

$P_{0}=$ Population in initial year 
$t=$ time period between initial year and year $t$ (in years).

If population growth is about the changing number of population within a specific period, density is more focused on the population and the total area in a specific location. Population density is the number of people per unit in a specific area [40]. The intent of density calculation is to measure the number of people living in an area and distinguish which locations are denser compared to others. The population density $(d)$ is determined as follows:

$$
d=\left(\frac{P_{0}}{A}\right),
$$

where, $d=$ density rate (people $/ \mathrm{km}^{2}$ )

$P_{0}=$ Number of Population

$A=$ Total Area $\left(\mathrm{km}^{2}\right)$.

\subsubsection{Rural-Urban Status}

Rural-urban status in this study was derived from variables and criteria that have been applied by BPS in determining rural-urban status in PODES data (1990, 2000, and 2010). These variables are population density, percentage of farming households, percentage of households served by electricity, percentage of households served by telephone network, access to main urban facilities, and access to supporting facilities. Variables and criteria in classifying rural-urban status are shown in Table 2 [39].

Table 2. Variables and criteria for rural-urban classification.

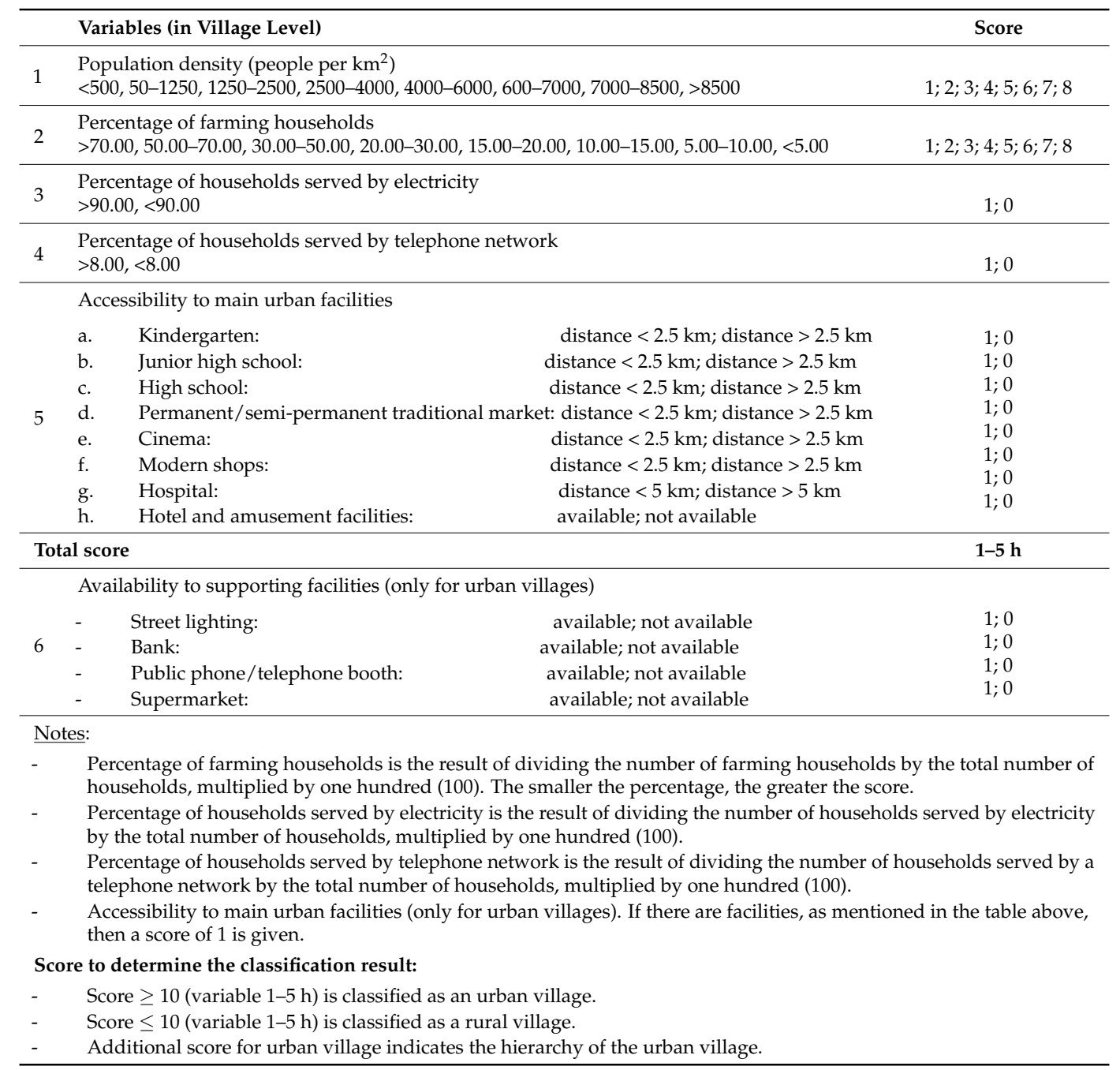




\subsubsection{Map Overlay}

In the final analysis step, data on population growth rate, distance to coastline, and type of disasters were combined by employing the overlay analysis in GIS. From the overlay analysis, the hazard events can be identified. By looking at the data cross-tabulation that resulted from the overlay analysis, the relationship between climate-related disasters and urbanization pressure, represented by population growth as well as distance from coastline, can then be shown. Figure 2 shows the typology of map overlay and cross-tabulation analysis in this study.

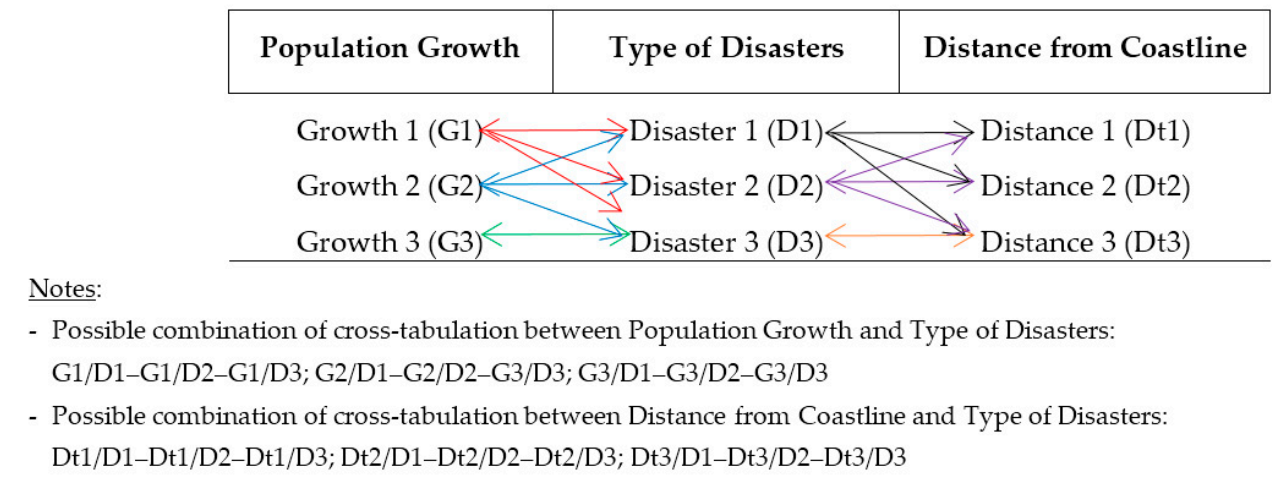

Figure 2. Typology of map overlay analysis.

\section{Results and Discussion}

\subsection{Urbanization in Central Java}

Based on the 2000 and 2010 censuses, Indonesia's population growth is $1.49 \%$. The rural population growth is $3.3 \%$, which is very low compared to urban population growth at $39 \%$. It is obvious that urbanization happens rapidly in the country. Table 3 shows that the share of urban population in Central Java is relatively low compared to other provinces of Java Island. The urban population on Java Island is $60.8 \%$, very much above the Indonesian average, i.e., $49.8 \%$. The projection to 2035 [41], however, indicates a similar pattern.

Urbanization, in general, is defined as an increase in urban population, but it is not the same as urban population growth. Urbanization is only taking place where urban population growth is higher than the general population growth, or where the urban share increases significantly with respect to the total population [17]. There are, at least, three factors influencing urbanization, including a natural increase in urban area, migration, and reclassification of rural and urban status, resulting in 'in situ' urbanization. Urban areas emerging because of a change in rural-urban classification is the main factor behind the high rate of urbanization in Indonesia, mainly since the 1990s [42].

Table 3. Urban population growth in 1990, 2000, and 2010.

\begin{tabular}{lccccccc}
\hline & $\begin{array}{c}\text { Urban Population } \\
\mathbf{1 9 9 0}\left(\mathbf{( ' 0 0 0 )}^{\prime}\right.\end{array}$ & $\begin{array}{c}\text { Urban Population } \\
\mathbf{2 0 0 0}\left({ }^{\prime} \mathbf{0 0 0}\right)\end{array}$ & $\begin{array}{c}\text { Urban Population } \\
\mathbf{2 0 1 0}\left({ }^{\prime} \mathbf{0 0 0}\right)\end{array}$ & $\begin{array}{c}\text { \% Urban } \\
\mathbf{1 9 9 0}\end{array}$ & $\begin{array}{c}\text { \% Urban } \\
\mathbf{2 0 0 0}\end{array}$ & $\begin{array}{c}\text { \% Urban } \\
\mathbf{2 0 1 0}\end{array}$ & $\begin{array}{c}\text { \% Urban 2035 } \\
\text { (Projected) }\end{array}$ \\
\hline Central Java & 7572 & 12,554 & 14,799 & 27.0 & 40.2 & 45.7 & 60.8 \\
\hline Java Island & 36,037 & 58,980 & 79,950 & 35.7 & 48.7 & 60.8 & 77.6 \\
\hline Indonesia & 55,434 & 85,381 & 118,320 & 30.9 & 42.4 & 49.8 & 66.6 \\
\hline
\end{tabular}

Considering the rural-urban status from the BPS data, Table 4 indicates that the percentage of urban villages in Central Java is much higher than the Indonesian average. The gap is even more significant in 2010 compared to 2000. During these 10 years (2000 to 2010), both urban villages in Central Java and Indonesia have nearly doubled in population. However, in composition, the difference of urban villages in 2000 and 2010 showed a significant change in urban villages' status in 
Central Java as compared to total urban villages in Indonesia. The composition showed that Central Java has quite rapid development in certain areas, particularly in areas directly adjacent to urban areas.

Table 4. Composition of urban and rural villages in 1990, 2000, and 2010.

\begin{tabular}{ccccccc}
\hline \multirow{2}{*}{ Years } & & \multicolumn{3}{c}{ Number of Villages } & \multicolumn{2}{c}{$\%$ of Villages } \\
\cline { 3 - 7 } & & Rural & Urban & Total & Rural & Urban \\
\hline \multirow{2}{*}{1990} & Central Java & 7168 & 1298 & 8466 & 84.7 & 15.3 \\
& Indonesia & 58,970 & 6566 & 65,536 & 89.9 & 10.1 \\
\multirow{2}{*}{2000} & Central Java & 7108 & 1435 & 8543 & 83.2 & 16.8 \\
& Indonesia & 61,273 & 7496 & 68,769 & 89.1 & 10.9 \\
\multirow{2}{*}{2010} & Central Java & 5861 & 2715 & 8576 & 68.3 & 31.7 \\
& Indonesia & 61,340 & 15,786 & 77,126 & 79.5 & 20.5 \\
\hline
\end{tabular}

Figure 3 illustrates that urbanization largely occurred in coastal areas. There are at least three main cities in Central Java located on the northern coast, including Semarang, Pekalongan, and Tegal. From 2000 to 2010, this coastal area developed significantly, with those three main cities and the adjacent areas getting increasingly larger in terms of population density and built-up area. In Indonesia, most of the urban centers are located along the coast. Related to Indonesian colonial history, harbors were the main gateway for trade. Seaports have continued to host the main economic activity and initiate urban development [28]. Jakarta, Surabaya, and Semarang are the three largest urban areas along the northern coast of Java, and all of them are supported by a seaport as part of their strategic urban infrastructure.

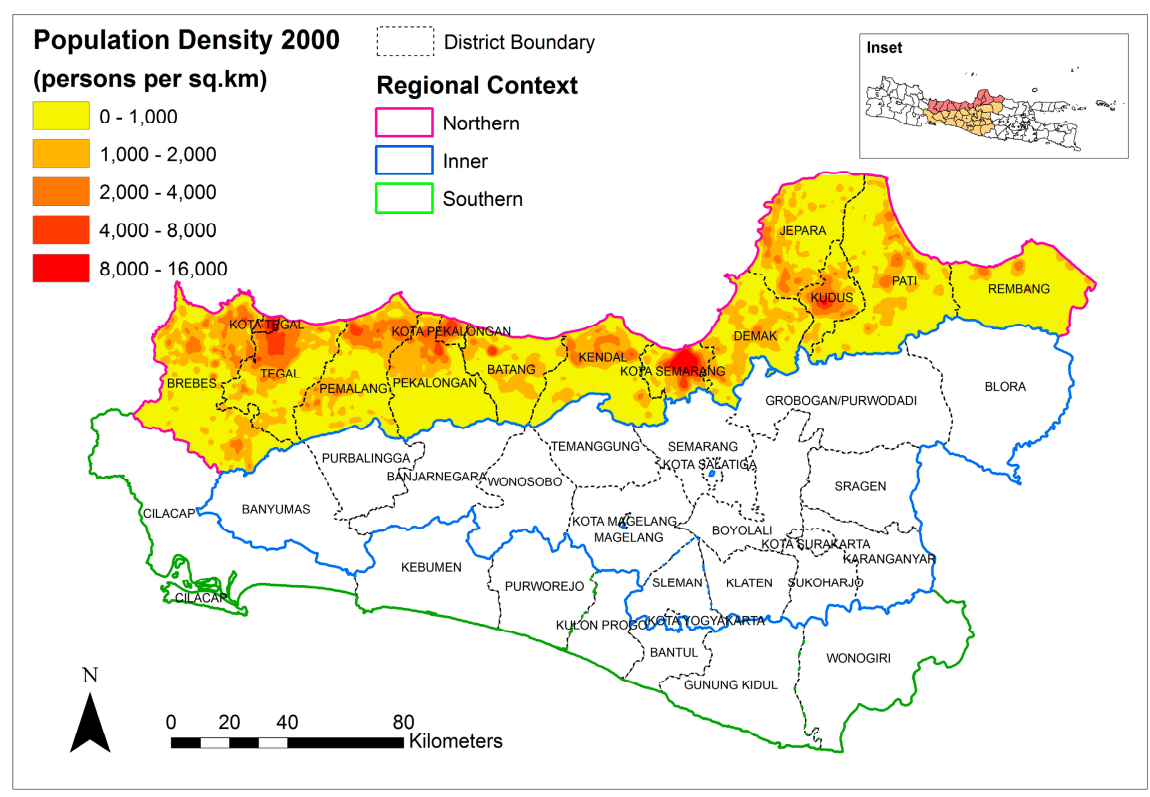

Figure 3. Cont. 


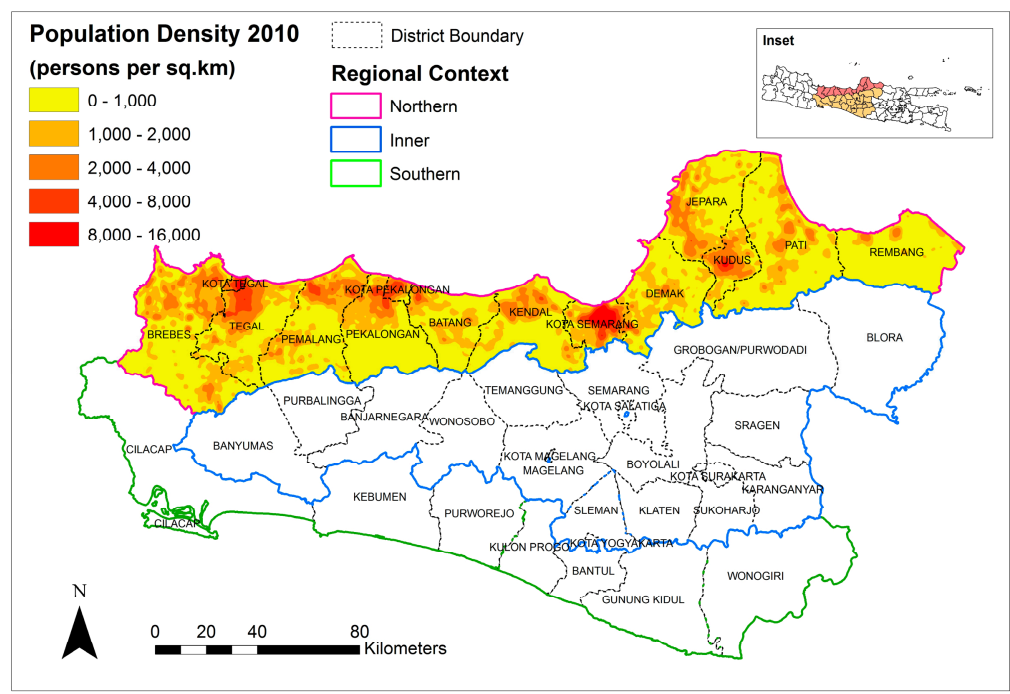

Figure 3. Population density in the northern coastal region of Central Java, 2000 and 2010.

\subsection{Urbanization in the Northern Coastal Area}

In Indonesia, Java Island is known as a fast-growing island with more than 137 million inhabitants. Java Island has become the most dynamic area of development and, therefore, continues to accelerate urbanization processes. The urbanization process itself has contributed to rapid urban development, including in coastal areas of northern Central Java. As shown in Table 5, around $40 \%$ of people in Central Java live in the northern coastal area, and $50 \%$ of the urban population is in this area. However, because of the emerging in situ urbanization located in the inner area of the island (see Figure 4), the proportion of urban villages located in the northern coastal area decreased from $50.7 \%$ in 2000 to $41.9 \%$ in 2010 .

Table 5. Comparison of total population, urban population, and urban village in 1990, 2000, and 2010.

\begin{tabular}{|c|c|c|c|c|c|c|c|c|c|c|c|c|}
\hline & \multicolumn{4}{|c|}{ Total Population } & \multicolumn{4}{|c|}{ Urban Population } & \multicolumn{4}{|c|}{ Urban Villages } \\
\hline & \multicolumn{2}{|c|}{ Central Java } & \multicolumn{2}{|c|}{ Northern Coastal } & \multicolumn{2}{|c|}{ Central Java } & \multicolumn{2}{|c|}{ Northern Coastal } & \multicolumn{2}{|c|}{ Central Java } & \multicolumn{2}{|c|}{ Northern Coastal } \\
\hline & Number & $\%$ & Number & $\%$ & Number & $\%$ & Number & $\%$ & Number & $\%$ & Number & $\%$ \\
\hline 1990 & $28,634,410$ & 100 & $11,425,057$ & 39.9 & $7,572,179$ & 100 & $3,913,231$ & 51.7 & 1298 & 100 & 688 & 53.0 \\
\hline 2000 & $31,219,629$ & 100 & $12,471,063$ & 39.9 & $8,546,793$ & 100 & 4,393,157 & 51.4 & 1435 & 100 & 727 & 50.7 \\
\hline 2010 & $33,497,821$ & 100 & $13,762,335$ & 41.1 & $13,541,123$ & 100 & $6,775,799$ & 50.0 & 2715 & 100 & 1138 & 41.9 \\
\hline
\end{tabular}

The change in status from rural to urban villages is indicated as the main cause of high urbanization in the 1990s and was a source of continued growth between 2000 and 2010 [41]. Industrialization does not necessarily take place as part of urban growth. Two types of industrialization are the driving force of urbanization in Central Java [37]. Industrialization from above leads to the classical urban growth model, whereby the changing rural-urban status takes place in urban fringe areas. In different types, in situ urbanization is derived from the endogenous process. Similar to the case of the Yangtze River Delta, rural industrialization has also led to the emergence of urban areas in locations that are not necessarily close to big cities [18]. Rural industrialization may also strengthen the role of small-medium-sized cities. Figure 4 shows the urban villages that emerged mainly between 2000 and 2010 but are not located close to core regions, which is an indication that in situ urbanization has been taking place in Central Java. 


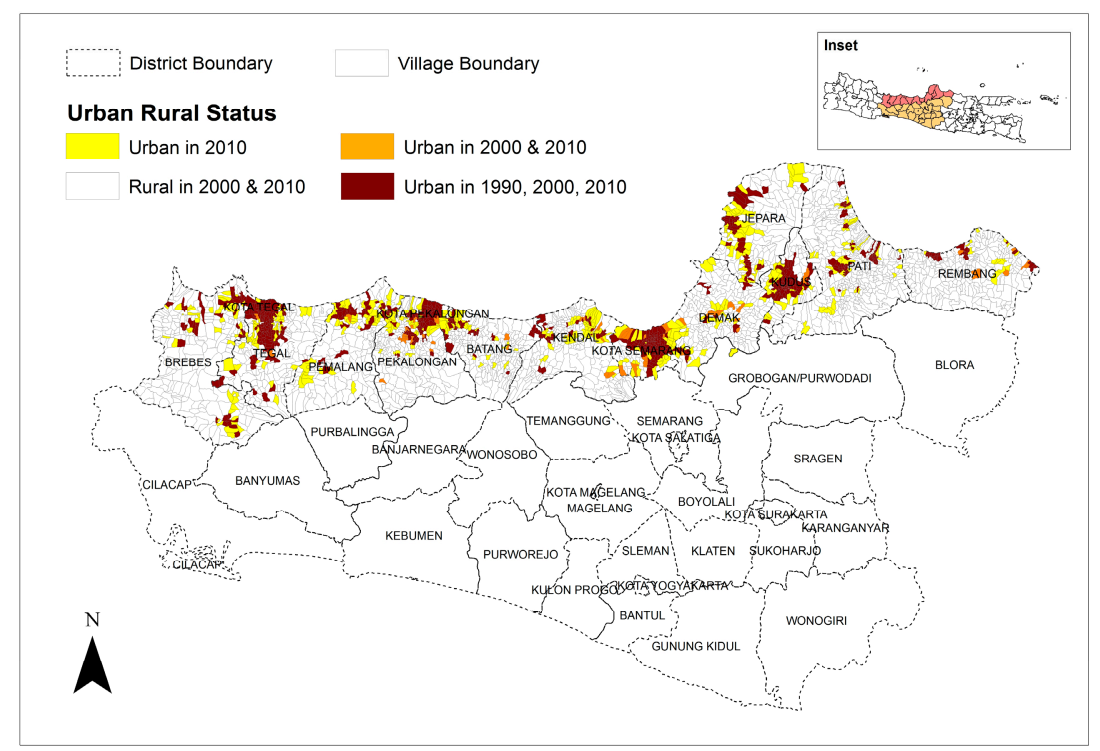

Figure 4. Urban rural status in the northern coastal region of Central Java; 1990, 2000, and 2010.

The population growth of coastal areas in Central Java had shown a locational preference for people living in areas where there is an opportunity of gaining access to coastal zones, especially related to the different resources available and being located near trading opportunities [10]. An increasing number of people living in and near coastal areas will increase disaster vulnerability since coastal areas protect residents against various hazards. Therefore, as shown in Figure 4, the number of urban status from 1990, 2000, and 2010 has shifted from in and near coastal zones to inland areas. For example, in Semarang City, population growth and development have been significantly shifting away from the coastline so the environmental risk is much less [43]. However, the development of Central Java is still strongly dominated by the cities located in the northern coastal areas [44].

\subsection{Climate-Related Disasters in the Northern Coastal Area}

Climate change has various different impacts on human activities. Drought will seriously influence agricultural activities [6]. Tidal fluctuations and changing dynamics from sea level rise and land subsidence are likely to influence people working in the fishery sector. Flooding will lead to a broader impact, not only in physical terms because of the damage to infrastructure caused by flooding, but also in socioeconomic terms, as people may not be able to conduct their daily activities. Ultimately, flooding is also regarded as the most frequent natural disaster in Asia, including in China and Indonesia [3,18,29].

Flooding was the most common and destructive disaster occurring in Central Java's coastal areas, followed by tidal flooding and droughts (see Table 6 and Figure 5). Of the total of 335 flooding events, about $40 \%$ were $10-\mathrm{km}$ from the coast and $20 \%$ were less than $5 \mathrm{~km}$ from the coast during 2010 . Tidal flooding occurs near the coastline: more than $80 \%$ of events were experienced at the distance of less than $5 \mathrm{~km}$ away. Drought events were more prevalent at a distance of 5 to $40 \mathrm{~km}$. However, in general, the distribution of hazard events showed a pattern where the closer the area is to the coast, the higher the number of events.

It is a common phenomenon that urbanization increases the flood risk as a result of urban development and concentration, which increases vulnerability [35]. To an even further extent, the number of flood events in cities around the world is attributed to the change in extreme precipitation due to climate change [4,45-48]. However, it is important to note that disaster is not mainly due to changing natural phenomena but rather to human activities. A large number of flood events do not necessarily take place within a short distance of the coastline. Urban concentration and various human 
activities have led people to seek new locations for settlement. This movement contributes to a large extent of land conversion that may increase flooding frequency due to poor infiltration and a reduction in flow resistance. Increasing urban area has also contributed to what is called the Urban Heat Island (UHI) effect, whereby the temperature of urban areas is higher than that of the surrounding areas [49]. Therefore, increasing UHI in a city is also followed by the enhancement of rainfall [49]. As found in some American cities, urban areas have a great influence in increasing rainfall rates from $28 \%$ to $30 \%$ within a specific distance [46,47].

Table 6. Different climate-related disasters distributed along the northern coastal area in 2010.

\begin{tabular}{cccc}
\hline \multirow{2}{*}{ Distance from Coastline } & \multicolumn{3}{c}{ Total Villages } \\
\cline { 2 - 4 } & Flood & Tidal Flood & Drought \\
\hline Less than $5 \mathrm{~km}$ & 80 & 53 & 6 \\
$5-10 \mathrm{~km}$ & 77 & 7 & 7 \\
$10-20 \mathrm{~km}$ & 136 & 5 & 8 \\
$20-40 \mathrm{~km}$ & 29 & - & 7 \\
More than $40 \mathrm{~km}$ & 13 & - & - \\
Total villages & 335 & 65 & 28 \\
\hline
\end{tabular}

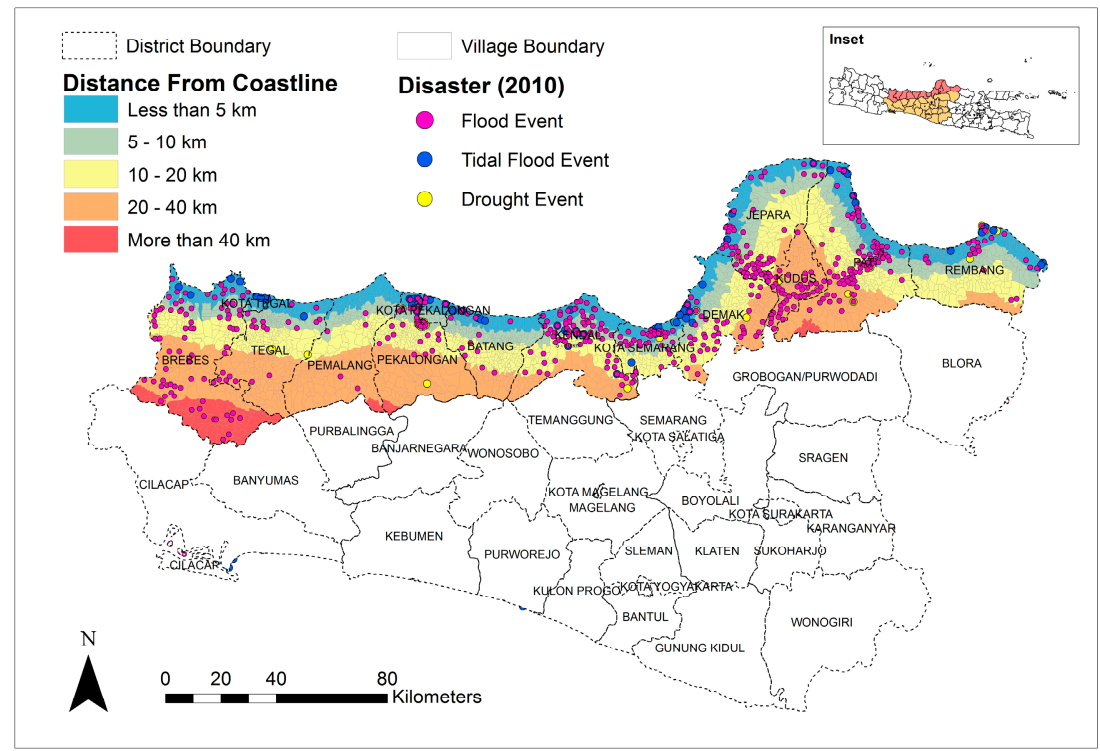

Figure 5. Distribution of different climate disasters in 2010.

\subsection{Urbanization and Climate-Related Disasters}

Urbanization in coastal areas has led to serious environmental problems. The increasing occurrence of climate disasters can be attributed to sea level rise [10,50]. A similar phenomenon was found in the coastal area of Java [20,28]. As shown in Figures 6 and 7, flood events in 2010 were mostly in areas with population growth less than $1 \%$, both in rural and urban areas in the coastal region of Central Java. However, in the second layer in urban area, flood events are found more consistently where there is a population growth rate of more than 3\% (18 events). In rural areas, a second layer of flood events were dominated by areas where the population growth rate is $1 \%$ to $1.99 \%$, with 79 events found. The flood events in the study area were mostly found in coastal settlements where human activities interact with poor infrastructure condition. 

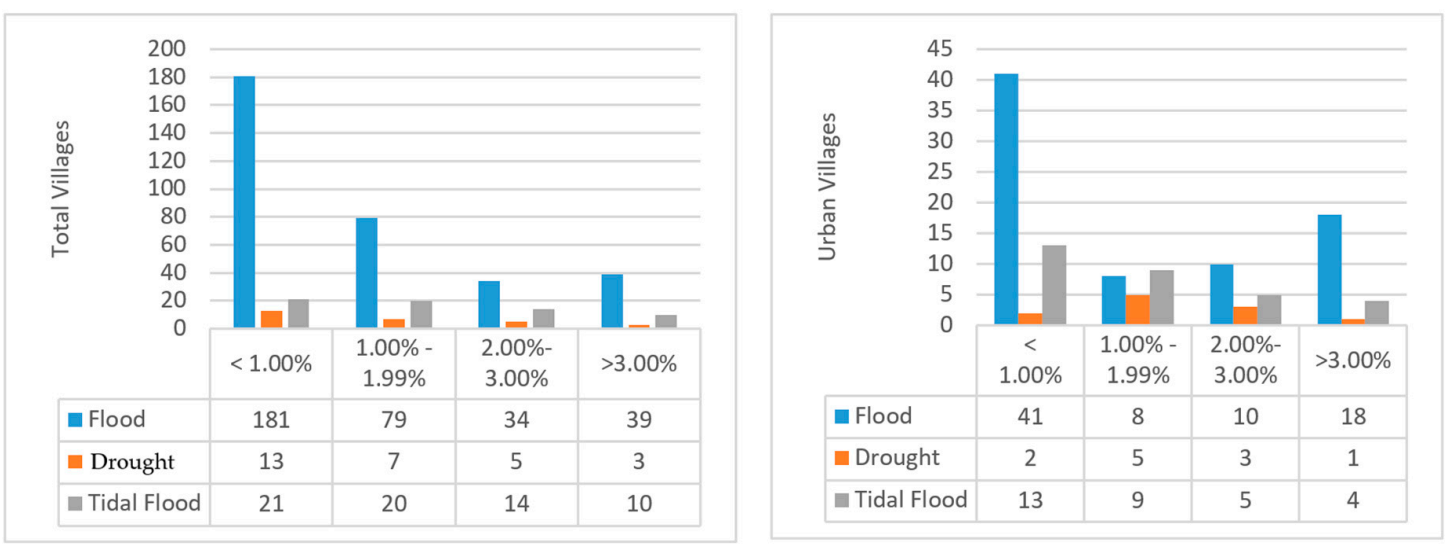

Figure 6. Distribution of different climate-related disasters within population growth rates in 2010.

Drought events were mostly distributed where there were moderate population growth rates in urban areas (45\%), while in rural areas, these events occurred more often in regions where there was a less than $1 \%$ growth rate (46\%). Drought events, both in rural and urban areas in the northern coastal region of Central Java, subsequently affected human life, particularly in terms of the need for water for different activities. From the field survey, drought in urban areas due to decreased rainfall has brought about a certain level of water shortage. People and the environment are the primary recipients of drought impact. Therefore, population growth is recognized as a major source of water problems in the future urban environment.

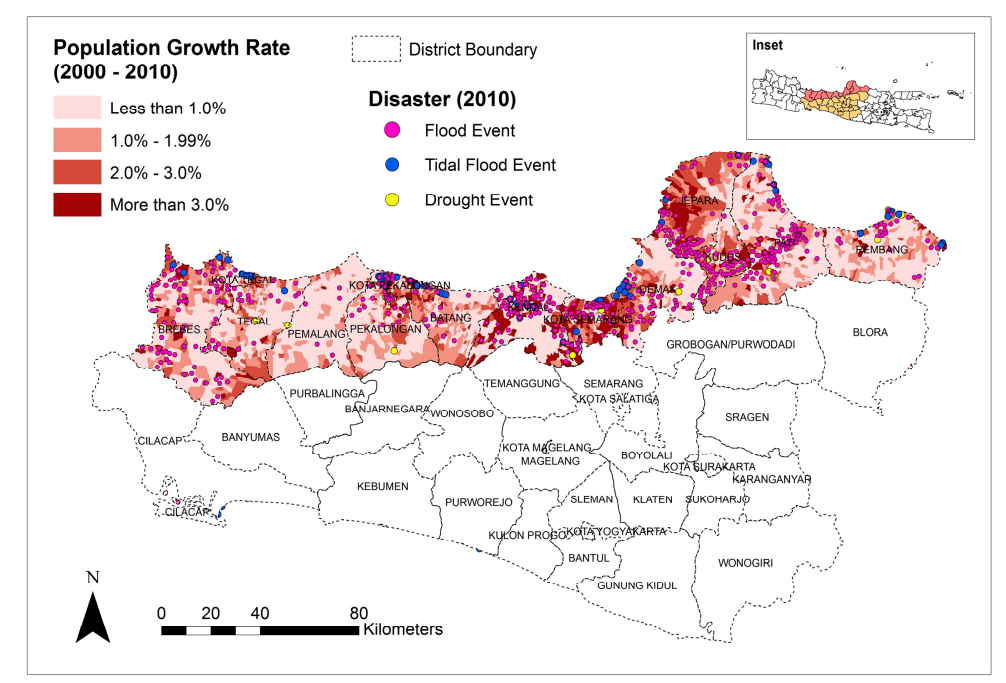

Figure 7. Spatial Distribution of different climate-related disasters within population growth rates in 2010.

It is also important to point out that population growth may reflect economic development. The phenomenon will lead to a significant change in the physical environment, which is land conversion. Land conversion should be followed by appropriate infrastructure support. Thus, as was the case with Can Tho City, Vietnam, there will be an increased risk that the emerging urban area will experience land conversion without good infrastructure planning support [35]. This may explain why flooding is also likely to happen in areas with lower population growth, regarded as newly growing regions. From the point of view of urban disaster governance, this becomes a major problem as most small-medium cities that experience disasters lack the budget and capacity to address the problem. As was also found in West Bengal, urban disaster governance in small-medium cities is a challenging 
issue [51]. The problem is not actually the urbanization itself but rather the planning and management of the city, particularly the provision of goods and services such as infrastructure [52].

In the end, discourse on urbanization and climate-related disasters is also related to the debate about balanced versus unbalanced development. Balanced development advocates believe that all centers of development (i.e., cities) should be allocated sufficient funds so there will be equal development among cities with comparable numbers of inhabitants. However, there are several counter-arguments stating that this policy theory is likely to ignore the fact that many regions still lack capital, mainly skilled labor and technology. Therefore, unbalanced development, in which the development would only be concentrated in a particular sector, is more prevalent in most Asian countries and has resulted in urban primacy. These phenomena take place in the study area, and have been leading to various environmental problems, including those related to climate change impacts. This may explain why some scholars who are inspired by the urban development in European cities [53-55] promote polycentric development as an ideal type of regional spatial structure. One concern is that, the polycentric model would be able to maintain society, the economy, and the environment in a good balance.

\section{Conclusions}

Climate-related disasters along the coast of Central Java are more dominant in areas with a low level of population growth. On the other hand, each type of disaster shows a different pattern: flooding was found in almost the whole study area, tidal floods typically occurred close to the coastline, while drought occurred quite a distance from the coastal area. The number of disasters is quite high in urban areas with high population growth. This indicates that urbanization to some extent influences the number of disasters. Urbanization has been leading to a higher risk of climate change impacts. As urbanization in Central Java take place not only as a part of the urban growth process but also via in situ urbanization, climate-related disasters on the northern coast have been spread out at a greater distance from the coastline and in areas with lower population growth.

Focusing on the regional level, the urbanization level of the northern coast of Central Java is likely growing as the population is increasing. Accordingly, this study proposes some future research directions and policy recommendations. First, spatial planning policy should be regarded as an important instrument to anticipate the urbanization pattern at a regional level. This requires deeper studies into spatial planning policy for promoting more balanced development between regions. Types of regional development such as polycentric development may be a good example where socioeconomic and spatial planning policy can reduce regional disparity. Second, there are challenges that should be addressed to enhance climate change adaptation strategies, including collaboration with communities and stakeholders. On the other hand, the distribution of hazard events in different locations within the study area requires the awareness of local authorities on the impact disasters will have on people and human settlements. Therefore, improving the awareness of people living in coastal areas becomes a major concern as the initial action comes from the local people. All efforts towards climate-related disaster mitigation and adaptation should be focused on human action.

This study is able to show the spatial development of urbanization as well as the regions or locations where more disasters take place. It was elaborated on a regional scale. However, climate-related disasters can be more effectively described at the micro level, where people, groups, and communities are directly impacted. Future research could focus on the relationship with and impact of urbanization in those two aspects, i.e., livelihood and the environment.

Acknowledgments: We would like to acknowledge all the team members for their efforts in collecting data during the field survey. This research was funded by Diponegoro University in collaboration with the Directorate of Research and Community Services (Direktorat Penelitian dan Pengabdian Masyarakat/DP2M)—Directorate General of Higher Education, Ministry of Research and Technology, Indonesia.

Author Contributions: Iwan Rudiarto: data collection and analysis, writing and finalization of the paper. Wiwandari Handayani: research design, data collection, improving and reviewing the paper. Jawoto Sih Setyono: refine research framework and polish English writing. 
Conflicts of Interest: The authors declare no conflict of interest.

\section{References}

1. Wamsler, C.; Brink, E.; Rivera, C. Planning for climate change in urban areas: From theory to practice. J. Clean. Prod. 2013, 50, 68-81. [CrossRef]

2. UNISDR. Making cities resilient: My city is getting ready (campaign kit). In 2012-2011 World Disaster Reduction Campaign; United Nations: New York, NY, USA, 2010.

3. Chandrappa, R.; Gupta, S.; Kulshrestha, U.C. Coping with Climate change: Principles and Asian Context; Springer Science \& Business Media: Berlin/Heidelberg, Germany, 2011.

4. IPCC. Climate Change 2007: Synthesis Report; Intergovernmental Panel on Climate Change: Geneva, Switzerland, 2007.

5. IPCC. Managing the risks of extreme events and disasters to advance climate change adaptation. In $A$ Special Report of Working Groups I and II of the Intergovernmental Panel on Climate Change; Field, C.B., Barros, V., Stocker, T.F., Qin, D., Dokken, D.J., Ebi, K.L., Mastrandrea, M.D., Mach, K.J., Plattner, G.-K., Allen, S.K., et al., Eds.; Cambridge University Press: Cambridge, UK; New York, NY, USA, 2012; p. 582.

6. Bhatta, G.D.; Aggarwal, P.K.; Shrivastava, A.K.; Sproule, L. Is rainfall gradient a factor of livelihood diversification? Empirical evidence from around climatic hotspots in Indo-Gangetic Plains. Environ. Dev. Sustain. 2016, 18, 1657-1678. [CrossRef]

7. Lins-de-Barros, F.M. Integrated coastal vulnerability assessment: A methodology for coastal cities management integrating socioeconomic, physical and environmental dimensions-Case study of Regiao dos Lagos, Rio de Janeiro, Brazil. Ocean Coast. Manag. 2017, 149, 1-11. [CrossRef]

8. Thao, N.D.; Takagi, H.; Esteban, M. (Eds.) Coastal Disasters and Climate Change in Vietnam: Engineering and Planning Perspectives; Elsevier: London, UK, 2014.

9. Beatley, T.; Brower, D.; Schwab, A.K. An introduction to Coastal Zone Management; Island Press: Washington, DC, USA, 2002.

10. McGranahan, G.; Balk, D.; Anderson, B. The rising tide: Assessing the risks of climate change and human settlements in low elevation coastal zones. Environ. Urban. 2007, 19, 17-37. [CrossRef]

11. Small, C.; Nicholls, R.J. A global analysis of human settlement in coastal zones. J. Coast. Res. 2003, 19, 584-599.

12. Wang, S.; Ma, H.; Zhao, Y. Exploring the relationship between urbanization and the eco-environment-A case study of Beijing-Tianjin-Hebei region. Ecol. Indic. 2014, 45, 171-183. [CrossRef]

13. Seto, K.C.; Satterthwaite, D. Interactions between urbanization and global environmental change. Curr. Opin. Environ. Sustain. 2010, 2, 127-128. [CrossRef]

14. Ntelekos, A.A.; Smith, J.A.; Krajewski, W.F. Climatological analyses of thunderstorms and flash floods in the Baltimore metropolitan region. J. Hydrometeorol. 2007, 8, 88-101. [CrossRef]

15. Smith, J.A.; Baeck, M.L.; Meierdiercks, K.L.; Nelson, P.A.; Miller, A.J.; Holland, E.J. Field studies of the storm event hydrologic response in an urbanizing watershed. Water Resour. Res. 2005, 41, W10413. [CrossRef]

16. Baeck, M.L.; Smith, J.A. Rainfall estimation by the WSR-88D for heavy rainfall events. Weather Forecast. 1998, 13, 416-436. [CrossRef]

17. UNFPA. Urbanization in Indonesia. Monograph Series 4; UNFPA: Jakarta, Indonesia, 2015.

18. Gu, C.; Hu, L.; Zhang, X.; Wang, X.; Guo, J. Climate change and urbanization in the Yangtze River Delta. Habitat Int. 2011, 35, 544-552. [CrossRef]

19. Orleans Reed, S.; Friend, R.; Toan, V.C.; Thinphanga, P.; Sutarto, R.; Singh, D. "Shared learning” for building urban climate resilience-experiences from Asian cities. Environ. Urban. 2013, 25, 393-412. [CrossRef]

20. Handayani, W.; Rudiarto, I.; Setyono, J.S.; Chigbu, U.E.; Sukmawati, A.M.A. Vulnerability assessment: A comparison of three different city sizes in the coastal area of Central Java, Indonesia. Adv. Clim. Chang. Res. 2017, 8, 286-296. [CrossRef]

21. Kumar, T.S.; Mahendra, R.S.; Nayak, S.; Radhakrishnan, K.; Sahu, K.C. Coastal vulnerability assessment for Orissa state, East Coast of India. J. Coast. Res. 2010, 26, 523-534. [CrossRef]

22. Sales, R.F.M., Jr. Vulnerability and adaptation of coastal communities to climate variability and sea-level rise: Their implications for integrated coastal management in Cavite City, Philippines. Ocean Coast. Manag. 2009, 52, 395-404. [CrossRef] 
23. Torresan, S.; Critto, A.; Valle, M.D.; Harvey, N.; Marcomini, A. Assessing coastal vulnerability to climate change: Comparing segmentation at global and regional scales. Sustain. Sci. 2008, 3, 45-65. [CrossRef]

24. Dickson, E.; Baker, J.L.; Hoornweg, D.; Tiwari, A. Urban Risk Assessments: Understanding Disaster and Climate Risk in Cities; World Bank Publications: Washington, DC, USA, 2012.

25. Smith, K.; Petley, D.N. Mass Movement Hazards. In Environmental Hazards-Assessing Risk and Reducing Disaster; Routledge: London, UK, 2009; pp. 205-226.

26. Central Bureau of Statistics. Population Density per $\mathrm{km}^{2}$ by Province. 2010. Available online: http:/ / www. bps.go.id/ (accessed on 30 March 2010).

27. Central Bureau of Statistics. Statistik Indonesia 2010; Central Bureau of Statistics: Jakarta, Indonesia, 2010.

28. Handayani, W.; Kumalasari, N.R. Migration as Future Adaptive Capacity: The Case of Java-Indonesia. In Environmental Change, Adaptation and Migration; Palgrave Macmillan: Basingstoke, UK, 2015; pp. 117-138.

29. Marfai, M.A.; King, L.; Singh, L.P.; Mardiatno, D.; Sartohadi, J.; Hadmoko, D.S.; Dewi, A. Natural hazards in Central Java Province, Indonesia: An overview. Environ. Geol. 2008, 56, 335-351. [CrossRef]

30. Handmer, J.; Honda, Y.; Kundzewicz, Z.W.; Arnell, N.; Benito, G.; Hatfield, J.; Mohamed, I.F.; Peduzzi, P.; $\mathrm{Wu}, \mathrm{S}$.; Sherstyukov, B.; et al. Managing the Risks of Extreme Events and Disasters to Advance Climate Change Adaptation. In A Special Report of the Intergovernmental Panel on Climate Change (IPCC); Cambridge University Press: Cambridge, UK; New York, NY, USA, 2012; pp. 231-290.

31. Nicholls, R.J.; Hanson, S.; Herweijer, C.; Patmore, N.; Hallegate, S.; Corfee-Morlot, J.; Chateau, J.; Muir-Wood, R. Ranking Port Cities with High Exposures and Vulnerability to Climate Extremes: Exposure Estimates; OECD Environment Working Papers No. 1; OECD Publishing: Paris, France, 2007.

32. Li, Y.; Zhang, X.; Zhai, X.; Ma, S.; Cao, H.; Cao, J. Assessing spatial vulnerability from rapid urbanization to inform coastal urban, regional planning. Ocean Coast. Manag. 2016, 123, 53-65. [CrossRef]

33. Birhanu, D.; Kim, H.; Jang, C.; Park, S. Flood risk and vulnerability of Addis Ababa City due to climate change and urbanization. Procedia Eng. 2016, 154, 696-702. [CrossRef]

34. Malalgoda, C.; Amaratunga, D.; Haigh, R. Challenges in creating a disaster resilient built environment. Procedia Econ. Financ. 2014, 18, 736-744. [CrossRef]

35. Huong, H.T.L.; Pathirana, A. Urbanization and climate change impacts on future urban flooding in Can Tho city, Vietnam. Hydrol. Earth Syst. Sci. 2013, 17, 379-394. [CrossRef]

36. Wahyudi, S.I.; Ni'am, M.F.; Le Bras, G. Problems, causes and handling analysis of tidal flood, erosion, and sedimentation in northern coast of Central Java: Review and recommendation. Int. J. Civ. Environ. Eng. 2012, 12, 65-69.

37. Hadayani, W. Rural-Urban Transition in Central Java: Population and economic structural changes based on cluster analysis. Land 2013, 2, 419-436. [CrossRef]

38. Rudiarto, I. Spatial Assessment of Rural Resources and Livelihood Development in [a] Mountain Area of Java: A Case from Central Java, Indonesia; Margraf Publishers: Weikersheim, Germany, 2010.

39. OECD. Data and Metadata Reporting and Presentation Handbook; OECD: Paris, France, 2007.

40. CBS. Pedoman Pencacahan Penentuan Status desa-kelurahan/Guidance for Rural-Urban Classification; CBS: Jakarta, Indonesia, 2000.

41. CBS. Indonesian Population Projection 2010-2035; CBS: Jakarta, Indonesia, 2013.

42. Firman, T.; Kombaitan, B.; Pradono, P. The dynamics of Indonesia's urbanization, 1980-2006. Urban Policy Res. 2007, 25, 433-454. [CrossRef]

43. Handayani, W.; Rudiarto, I. Dynamics of Urban Growth in Semarang Metropolitan-Central Java: An Examination Based on Built-Up Area and Population Change. J. Geogr. Geol. 2014, 6, 80. [CrossRef]

44. Tirtosudarmo, R. Social transformation in the Northern coastal cities of Java: A comparative study in Cirebon and Gresik. J. Indones. Soc. Sci. Humanit. 2011, 3, 161-170.

45. IPCC. Climate Change and Biodiversity; Technical Paper-V; Intergovermental Panel on Climate Change: Geneva, Switzerland, 2002.

46. Shepherd, J.M.; Pierce, H.; Negri, A.J. Rainfall modification by major urban areas: Observations from spaceborne rain radar on the TRMM satellite. J. Appl. Meteorol. 2002, 41, 689-701. [CrossRef]

47. Mote, T.L.; Lacke, M.C.; Shepherd, J.M. Radar signatures of the urban effect on precipitation distribution: A case study for Atlanta, Georgia. Geophys. Res. Lett. 2007, 34. [CrossRef]

48. Dixon, P.G.; Mote, T.L. Patterns and causes of Atlanta's urban heat island-initiated precipitation. J. Appl. Meteorol. 2003, 42, 1273-1284. [CrossRef] 
49. Seto, K.C.; Kaufmann, R.K. Urban growth in South China and impacts on local precipitation. In Proceedings of the 5th Urban Research Symposium, Marseille, France, 28-30 June 2009.

50. Bosello, F.; De Cian, E. Climate change, sea level rise, and coastal disasters. A review of modeling practices. Energy Econ. 2014, 46, 593-605. [CrossRef]

51. Rumbach, A. Decentralization and small cities: Towards more effective urban disaster governance? Habitat Int. 2016, 52, 35-42. [CrossRef]

52. Pares-Ramos, I.K.; Alvarez-Berrios, N.L.; Aide, T.M. Mapping urbanization dynamics in major cities of Columbia, Ecuador, Peru, and Bolivia using night-time satellite imagery. Land 2013, 2, 37-59. [CrossRef]

53. Glasson, J.; Mashall, T. Regional Planning; Routledge: London, UK, 2007.

54. Davoudi, S. Polycentricity in European spatial planning: From an analytical tool to a normative agenda. Eur. Plan. Stud. 2003, 11, 979-999. [CrossRef]

55. Kloosterman, R.C.; Musterd, S. The polycentric urban region: Towards a research agenda. Urban Stud. 2001, 37, 623-633. [CrossRef]

(C) 2018 by the authors. Licensee MDPI, Basel, Switzerland. This article is an open access article distributed under the terms and conditions of the Creative Commons Attribution (CC BY) license (http:/ / creativecommons.org/licenses/by/4.0/). 